\title{
Mini-RT 装置用高温超伝導磁気浮上コイルの開発
}

\author{
柳 長門 ${ }^{\dagger}$ ，三戸 利行，森川 惇二*1，小川 雄一*1，濱口 真司， \\ 菱沼 良光，大國 浩太郎*1 ${ }^{*}$ 堀 暖*1, 岩熊 成卓*2, 上出 俊夫*3
}

\section{Engineering Development of an HTS Floating Coil for the Mini-RT Project}

\author{
Nagato YANAGI, Toshiyuki MITO, Junji MORIKAWA*1, Yuichi OGAWA*1, Shinji HAMAGUCHI, \\ Yoshimitsu HISHINUMA, Kotaro OHKUNI*1 ${ }^{1}$, Dan HORI*1 ${ }^{1}$, Masataka IWAKUMA*², and Toshio UEDE*3
}

\begin{abstract}
Synopsis: A magnetically-levitated superconducting coil device, Mini-RT, has been constructed using a high temperature superconductor (HTS) for the purpose of examining a new magnetic confinement scheme of high-beta non-neutral plasmas. The floating coil is wound with silver-sheathed Bi-2223 tapes, and it is operated in the temperature range of 20-40 K. A number of studies and experiments were carried out in order to realize the necessary system. One of them was to demonstrate magnetic levitation using a miniature HTS floating coil having a diameter of $80 \mathrm{~mm}$. The coil was fabricated using Bi-2223/Ag tapes of $12 \mathrm{~m}$ and excited by field cooling with liquid nitrogen. The magnetic levitation was examined using a real-time feedback control system with laser displacement gauges. Additionally, a persistent current switch (PCS) has been developed using Bi-2223/Ag tapes of $21 \mathrm{~m}$, and a prototype HTS-PCS was tested in a cryostat. After construction of the floating coil and HTS-PCS for the Mini-RT device was completed, excitation tests were carried out in the cryostat and the basic properties up to the nominal operation condition were examined.
\end{abstract}

Keywords: Bi-2223, HTS, HTS-PCS, magnetic levitation, Mini-RT

\section{1. はじめに}

新しい電磁流体力学的緩和過程を用いた高ベータ非中性 プラズマの閉じ込めシナリオが， Mahajan と Yoshida によ って提唱された ${ }^{1,2)}$.この閉じ込め方式では, ダイポール型 の磁場配位を用いるとともに，非中性化したプラズマ中に 発生する電場を用いてプラズマを高速で回転させることで, 電磁流体力学的に安定な緩和状態を実現する。（閉じ込め

\footnotetext{
Received April 16,2004

核融合科学研究所

于 509-5292 岐阜県土岐市下石町 322-6

National Institute for Fusion Science, 322-6 Oroshi-cho, Toki, Gifu 509-5292, Japan

*1 東京大学

于113-8656 東京都文京区弥生 2-11-16

The University of Tokyo, 2-11-16 Yayoi, Bunkyo-ku, Tokyo 113-8656, Japan

*2 九州大学

干 812-8581 福岡県福岡市東区箱崎 6-10-1

Kyushu University, 6-10-1 Hakozaki, Higashi-ku, Fukuoka, Fukuoka 812-8581, Japan

*3 富士電機システムズ

干210-9530＼cjkstart神奈川県川崎市川崎区田辺新田 1-1

Fuji Electric, 1-1 Shinden, Tanabe, Kawasaki-ku,

Kawasaki,Kanagawa 210-9530, Japan

† E-mail:yanagi@LHD.nifs.ac.jp
}

原理の詳しい解説については，文献 3）を参照）。これに より，超高ベータ（ただし，ベータはプラズマの圧力と閉 じ込め磁場の磁気圧力との比）のプラズマを閉じ込めるこ とができると理論的に予想され, 将来の核融合炉への応用 としても非常に魅力的であると言える. 閉じ込めに必要と されるダイポール型の磁場配位は, プラズマ中に浮遊させ たトーラス状の「内部導体」によって発生することが可能 である。ただし, 内部導体を用いて実際に高温プラズマの 生成を行うためには，プラズマと干渉することのないよう に, 給電ケーブルを必要としない磁気浮上超伝導リングの 使用が不可欠である。

東京大学高温プラズマ研究センターでは，この閉じ込め シナリオについて実験的に研究すること, および, そのた めの超伝導磁気浮上コイルを用いた装置システムの技術開 発を行うことを目的として，一連のプロジェクトが進めら れている。現在の目標は, 中型規模の装置となる “S-RT (Superconducting Ring-Trap)” 装置を建設することである ${ }^{2)}$ が, この装置は直径 $800 \mathrm{~mm}$, 起磁力 $500 \mathrm{kA}$, 重量約 $200 \mathrm{~kg}$ の超伝導磁気浮上コイルを有するものとなり, 技術的にチ ヤレンジングな課題が多い. S-RT 装置は, プラズマ閉じ込 
めに関する物理コンセプトは異なるものの, 現在マサチュ 一セッツ工科大学において（コロンビア大学との共同研究 によって）建設が進められている超伝導磁気浮上装置 “LDX (Levitated Dipole Experiment)” 4) と同規模で類似し た装置となる計画である.

S-RT 装置を実際に建設するためには，まず，超伝導磁気 浮上システムに関する技術的な課題を克服することが必須 である．特に，超伝導コイルは，磁気浮上に適するように 強力な磁場を発生できるとともに軽量であることが求めら れ，かつ，外部に突き出た給電ケーブルや冷却配管，計測 線等を一切持たない構造であることが必要である。このた め, 様々な特殊な技術課題が要求される. そこで, まずは, 必要な技術課題の抽出および克服と小規模なプラズマ実験 の遂行を目的として, 小型装置の建設が行われることが決 定された。“Mini-RT”と名付けられたこの装置は，直径 300 $\mathrm{mm}$, 重量約 $17 \mathrm{~kg}$ の磁気浮上超伝導コイルを有する。（コ イルの諸元と断面図，および，設計の詳細については，文 献 5）を参照.）磁気浮上中には超伝導コイルの冷却を行 うことが困難であるため, 長時間の磁気浮上を実現するた めには，コイルに十分な熱容量を持たせることが必要とな る.Mini-RT 計画では， 8 時間の磁気浮上を行うことが目 標とされたが，技術的検討を行った結果，このように小さ なサイズの超伝導コイルをこれほど長時間に渡って磁気浮 上させることは，金属系超伝導線材を用いる方式では実現 が難しいことが明らかとなった ${ }^{5)}$. そこで，超伝導線材自 身の持つ大きな比熱を有効に利用できる高温超伝導 (HTS) 線材の採用が不可欠であると判断され，銀シース Bi-2223 テープ線材を採用し，20-40 K の温度範囲で運転すること が基本計画となった ${ }^{5)}$ 。これは，同線材に関する近年の飛 躍的な技術的進歩に基づいて可能となった選択である ${ }^{6,7)}$.

Mini-RT 装置用磁気浮上コイルの特色のひとつは，直接 励磁方式を採用しており, 着脱式電流フィーダを用いて外 部電源から直接コイルに給電することにある。これは, LDX 装置が磁気誘導によって励磁を行うことと対照的で ある. LDXでは，巻線に金属系低温超伝導線材である二才 ブスズが用いられているのに対し，Mini-RT では酸化物系 HTS 線材を用いていることで温度の変化領域が大きいた め，フレキシブルな運転を実現することをひとつの目的と してこの方式が採用された。 また，励磁用超伝導コイルを 削減しコストダウンを図ることも重要な選択であった。一 方, 直接励磁を行うためには, 永久電流スイッチ(Persistent Current Switch; PCS)の採用が必要不可欠であるが，このコ イルの場合，PCS もメインコイルの巻線と同じ温度範囲で 動作することが要求されるため, メインコイルと同様に銀 シース Bi-2223 線材を用いることとした。これについては, これまでに他の装置用として製作された類似の PCS の製 作例 ${ }^{8)}$ を参考として, Mini-RT の超伝導コイルに最適なも のとなるように設計・製作を行うこととなった。
本論文では, Mini-RT 装置用 HTS 磁気浮上システムを開 発するために行った一連の工学 R\&D の成果についてまと める。まず, 磁気浮上制御システムの開発を行うことを目 的として：ミニチュアの HTS コイルを製作し，これを用い て大気中で実際に磁気浮上実験を行った。次に，HTS 永久 電流スイッチ(HTS-PCS)のプロトタイプを製作し，液体へ リウムを有したクライオスタットを用いて単体試験を行い, その性能確認を行った. 最後に, Mini-RT 実機に用いる浮 上超伝導コイルと HTS-PCS の組み合わせについて, 同様に クライオスタットを用いた単独励磁試験を行い, 動作特性 の確認を行った. これらの結果について以下にまとめる.

\section{2. ミニチュアHTS 磁気浮上コイル}

\section{1 ミニチュア HTS 磁気浮上コイルの設計と製作}

Mini-RT 装置では, 超伝導コイルの磁気浮上は, 浮上コ イルの上部に設置した銅製吊り上げ用コイルの電流值を浮 上コイルの位置（浮上高さ）に応じてフィードバック制御 することによって実現する. 現状のシステムでは, 浮上コ イルの位置検出のために高精度のレーザ距離計を用いてい る. 制御システムの開発は, まず永久磁石を磁気浮上させ ることから着手された。このために, 小型の磁気浮上試験 装置 FB-RT が製作され, PID 制御システムを用いて永久磁 石の安定な磁気浮上を行うことが可能となった ${ }^{9}$. これに より, Mini-RT に対して同様の制御システムを導入するこ とで技術的には対応可能であるとの見通しが得られたが, 実機に適用する前に実際に超伝導コイルを用いて磁気浮上
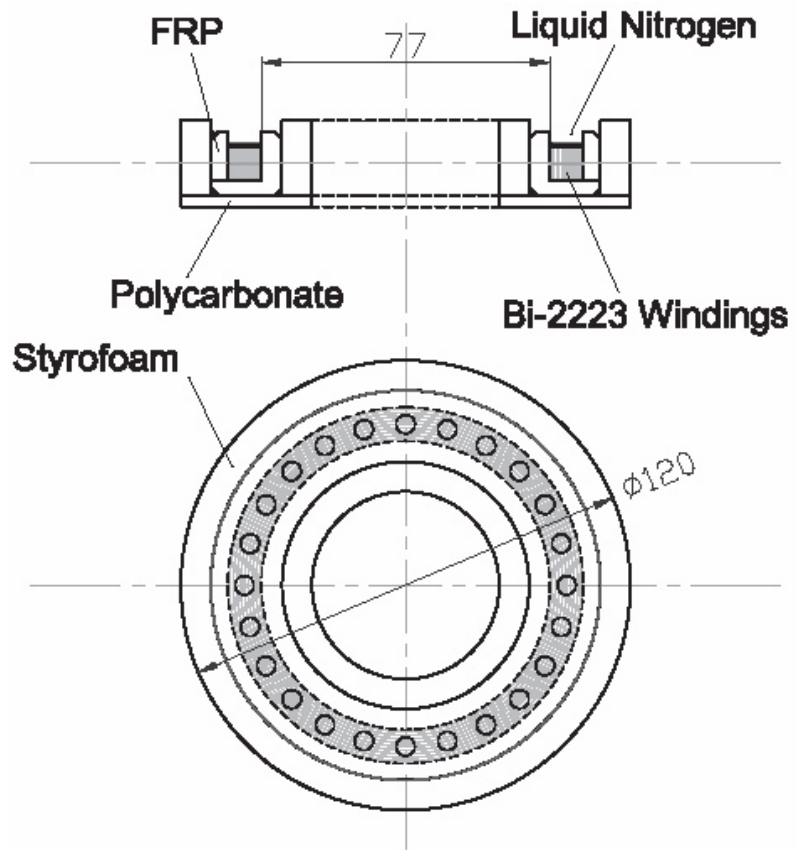

Fig. 1 Schematic illustrations of the miniature HTS floating coil for the FB-RT experiment (unit: $\mathrm{mm}$ ). 
Table 1 Specifications of the miniature HTS floating coil for the FB-RT experiment

\begin{tabular}{|l|c|}
\hline Inner / Outer Diameter & $77 / 94.5 \mathrm{~mm}$ \\
\hline Number of Turns & 44 \\
\hline Winding Method & Double pancake \\
\hline Inductance & $0.27 \mathrm{mH}$ \\
\hline Cable Type & $\begin{array}{c}\text { Ag-sheathed Bi-2223 } \\
\text { (reinforced by S.S. foils) }\end{array}$ \\
\hline Cable Supplier & American Superconductor \\
\hline Cable Width / Thickness & $4.1 / 0.3 \mathrm{~mm}$ \\
\hline Insulation between Turns & Kapton tape \\
\hline Cable Length & $12.0 \mathrm{~m}$ \\
\hline Nominal Current & $47 \mathrm{~A}$ \\
\hline Critical Current $(77 \mathrm{~K}$, s.f.) & $118 \mathrm{~A}$ \\
\hline Coolant & Liquid nitrogen \\
\hline Weight (including LN 2 ) & $321 \mathrm{~g}$ \\
\hline
\end{tabular}

試験を行い，動作確認を行うことが重要であると判断され た。ただし，この試験では，レーザ距離計を用いた浮上制 御を簡便に行うために, 磁気浮上は大気中で行う構造を採 用することとした，そのため，HTS 線材を用いてコイルを 製作し液体窒素冷却によって超伝導永久電流を実現するこ とが現実的に実現可能な手段と判断された。こうした経緯 より, 銀シース Bi-2223 テープ線材全長 $12 \mathrm{~m}$ を用いてミニ チュアコイル（平均直径 $84 \mathrm{~mm}$ ）の製作を行った．コイル の断面図と平面図を Fig. 1 に示寸。また，コイルの主要諸

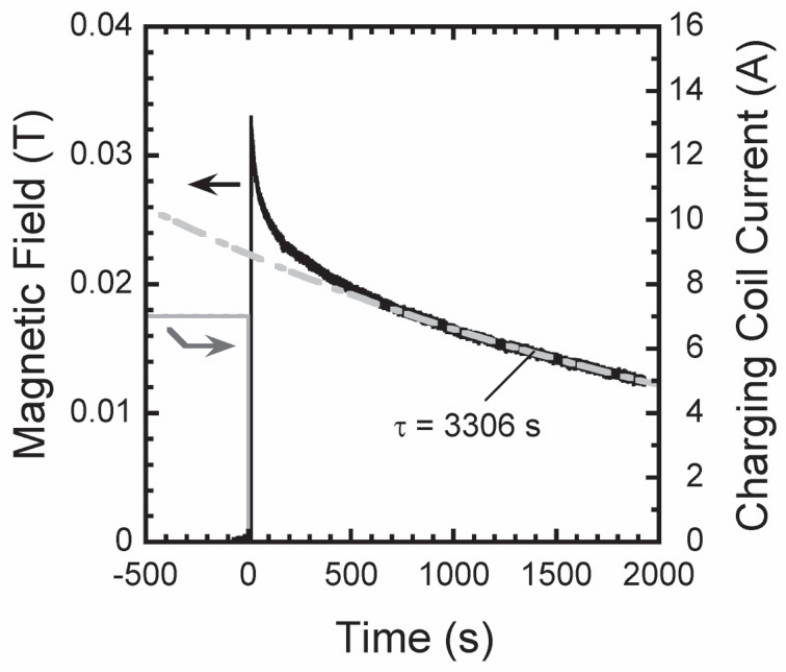

Fig. 2 Waveform of the magnetic field measured by a Hall probe at the center of the FB-RT HTS coil. The measurement started $12 \mathrm{~s}$ after turning off the current in the primary coil. The cable current of the HTS coil is estimated to be $47 \mathrm{~A}$ when the magnetic field is $0.03 \mathrm{~T}$. The dash-dotted line indicates an exponentially decaying curve of the magnetic field over a long period of time.
元を Table 1 に示す. 線材には, ステンレス箔によって機 械的な補強がなされたタイプ 6)を使用した。液体窒素温度 における臨界電流は, 118 A である（自己磁場， $1 \mu \mathrm{V} / \mathrm{cm}$ の条件). 超伝導コイルは, 全 44 ターンの巻線からなるダ ブルパンケーキで構成し, 巻線の最初と最後を接続した短 絡コイルとしている. 巻線作業を行うために小型の手動巻 線機を用意し, 線材を内径 $77 \mathrm{~mm}$ の FRP 製ボビンに慎重 に巻き付けた. また, 線材の外周面にカプトンテープを貼 り付けることによって巻線間の絶縁を施した。機械的強度 を確保することと，冷却や昇温時に水分が巻線間に侵入す ることを避けるために, エポキシ系の接着剤を用いて巻線 の固定を行った。巻線の両端は長さ約 $150 \mathrm{~mm}$ に渡って, 半田付けにより接続をした. FRP 製のボビンには溝を設け, この中に液体窒素を溜められる構造とするとともに, 大気 中で数分間液体窒素が保持できるように, ボビンの外周に は発泡スチロール製の断熱材を取り付けた.

\section{2 ミニチュアHTS コイルの励磁実験}

上記の要領で製作したミニチュア HTS コイルの励磁は, “フィールドクーリング法”を用いて行った。 すなわち, コイルの冷却前より外部コイルを用いて磁場を与えておき, この状態で液体窒素冷却によって浮上コイルを超伝導転移 させた後に, 外部コイルを減磁することによって浮上コイ ルに電流を誘起した. Fig. 2 に, 浮上超伝導コイルに誘起さ れた永久電流により生成されたコイル中心磁場の時間変化 を示す. 永久電流の作る磁場は, コイルの励磁直後には比 較的早く減衰しているが，時間とともに減衰時定数が長く なっていく様子が確認できる，後半のゆっくりとした減衰 については，接続抵抗によって説明できると考えられる. この場合, 計算で求められるコイルの自己インダクタンス

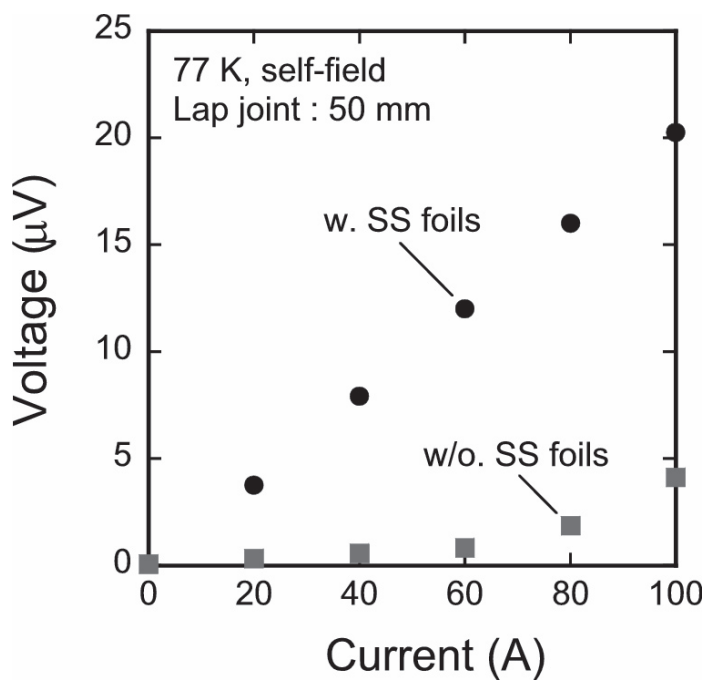

Fig. 3 Dependence of the joint voltage of Bi-2223 tapes on the transport current. Two samples with and without stainless-steel foils were measured. 
$0.27 \mathrm{mH}$ を実測された減衰時定数 3306 秒で割ると，接続抵 抗が $84 \mathrm{n} \Omega$ ほどであると算出できる。このことを検証するた めに, サンプル試験により接続抵抗測定を実施した。結果 をFig. 3 に示す.この試験では, 接続長 $50 \mathrm{~mm}$ のサンプル について液体窒素中で最大電流 $100 \mathrm{~A}$ まで通電し, 得られた 電圧-電流曲線の傾きより, 接続抵抗が $200 \mathrm{n} \Omega$ ほどであるこ とが求められた。この結果より，接続長 $150 \mathrm{~mm}$ に対する接 続抵抗としては $67 \mathrm{n} \Omega$ ほどであると求められるため, 上記の 減衰時定数より算出された值に近いものと判断することが できる. Fig. 3 では, 同じ線材でステンレス䇴の補強を取り 除いたサンプルについても測定を行っているが，実際の浮 上コイルでは，機械的な補強を優先してステンレス筞を付 けたままの線材で接続を行った。

一方, Fig. 2 の永久電流の減衰波形について, 励磁直後に おける早い減衰は，HTS 線材の磁束フロー抵抗によるもの と推測される。この時定数を計算によって評価するために は，線材で発生する磁束フロー抵抗を正確に求める必要が ある 10)が，コイルが 1 個のダブルパンケーキから構成され ているため，1本の線材内でも磁場分布が生じ，これによ って線材内部の電流分布も非一様になるものと考えられる ため，その評価は難しいものがある.

\section{3 ミニチュアHTS コイルの磁気浮上実験}

フィールドクーリング法による励磁によって，ミニチュ ア HTS コイルで永久電流が実現できることが実証できた ため, 次に, これを FB-RT 装置に装着して実際に磁気浮上 実験を行った。その様子を Fig. 4 に示す。この例では，3 本のレーザビームをコイルの底面に当て，これらから得ら れる距離信号の平均值を取ることによりコイルの平均的な 浮上高さを算出している。また，この值をもとにリアルタ イムで吊り上げコイルの電流值のフィードバック制御を行 っている，この場合，3本のレーザビームを用いることに よって，コイルが水平面から傾いた場合にも局所的な変位

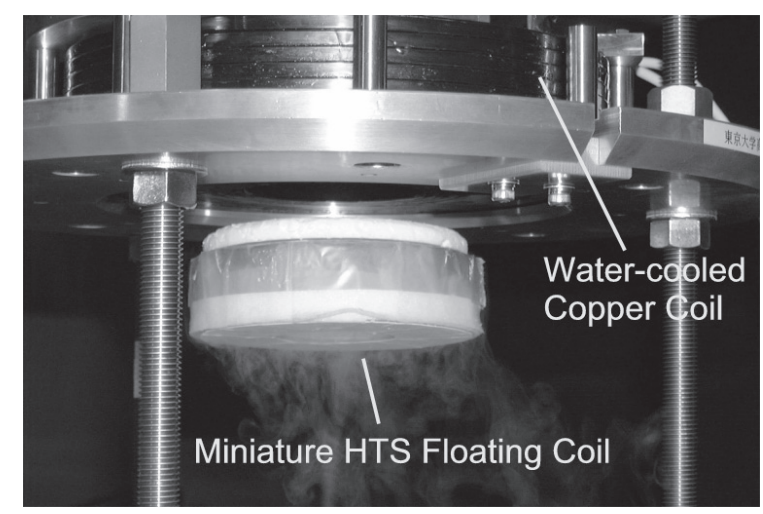

Fig. 4 Photograph of the FB-RT HTS floating coil during a magnetic levitation experiment. The bottom surface of the floating coil is irradiated by three laser beams for the positional measurement.
の影響を受けることなく, 安定な磁気浮上を実現すること ができており，実機の Mini-RT 装置でも同様の構成が採用 されることとなった。また，レーザ距離計の測定值より， 浮上位置の制御として $30 \mu \mathrm{m}$ 程度の精度があることも確認 できた．ただし，このコイルでは，外側に簡易断熱を施し たのみであったため, 液体窒素の蒸発によって浮上時間が 制限され，最高浮上時間としては 5 分ほどに留まった。ま た, 液体窒素の蒸発に伴う冷気の発生によってレーザビー ムが擾乱を受け，これによって浮上制御の誤差が大きくな ってしまうという特殊な問題も発生した。

以上の実験を通して Mini-RT 装置の磁気浮上制御システ ムを完成させるために必要とされる有益なデータを得るこ とができたと判断された。また，この実験は，超伝導コイ ルの磁気浮上を実際に経験するという意味でも意義の大き いものであったと言える.

\section{HTS-PCS の単体性能試験}

Mini-RT 装置用の HTS 磁気浮上コイルシステムを開発す るに当たって行った次の工学 R\&D は, 永久電流スイッチ (HTS-PCS)の開発である. 磁気浮上超伝導コイルの励磁につ いては，これをできるだけ短時間で行うことが要求される ため，HTS-PCS には，才フ時の抵抗をできるだけ高くする ことが求められる. 具体的には, Mini-RT の浮上コイルは自 己インダクタンスが $88 \mathrm{mH}$ であり，これを 1 分程度で定格 電流の約 $120 \mathrm{~A}$ まで励磁する必要がある。ここで, PCS はメ インコイルと同様に銀シース Bi-2223 線材を用いて製作さ れるため，才フ時の抵抗を大きくするためにあまり線材量 を多くすると, PCS の温度上昇に必要となる投入熱量が大 きくなってしまう。このため, 許容できる範囲内で線材量 は必要最低限としたい。ただし，一方で線材量が少なすぎ ると, 必要なオフ抵抗が確保できたとしても, コイルの永 久電流モードへの移行後に万一 PCS がクエンチした場合, 線材の温度上昇が厳しくなる。これらの条件を鑑み, 実際 の設計では, PCS 部に流れる電流を全電流の $1 \%$ 以下に抑え ること, コイルのクエンチ時における PCS 線材の最大許容 温度上昇を $135 \mathrm{~K}$ とすることの条件を加えて検討を行った。 その結果, 最終的に, 銀シースにマンガンを重量比 $0.3 \%$ 含 んだ線材を全長 $21.2 \mathrm{~m}$ 用いて PCS を構成する設計とし, 臨 界温度直上のオフ抵抗として $0.27 \Omega$ を確保した。だし, 線材の臨界電流は, メインコイル巻線のものより低く, 温 度 $77 \mathrm{~K}$ において $52.5 \mathrm{~A}$ である。

上記の長さの線材を用いて PCS を構成するには，これを コイル状に巻く必要があるが, HTS-PCS のオン・オフに伴 ってメインコイルの電流が変化することを避けることを目 的として, HTS-PCS は無誘導巻（バイファイラ巻）とし, 同心円構造でメインコイルの外周部にギャップ $2 \mathrm{~mm}$ を介 して設置するものとした，線材は，外径 $337 \mathrm{~mm}$ の真鍮製ボ ビンの溝に 20 ターン巻き込まれており, 内部に約 $100 \mathrm{~mm}$ 
の接続部を有する．また，PCS 巻線の内側には，20 ターン のマンガニンヒータが仕込まれており，これを用いて温度 上昇させることにより PCS をオフとする，ヒータの定格パ ワーは $53 \mathrm{~W}$ として，3 分程度で臨界温度まで到達する設計 とした. ただし, ヒータパワーの 5 分の 1 程度が実際に PCS 用線材に入熱されると概算している.

上記のような設計でHTS-PCS が製作されることになった が，実際にその性能を確認することは重要であると判断し たため，プロトタイプを実際に製作し，その性能試験を行 うこととなった. Fig. 5 に, HTS-PCS プロトタイプの外観を 示す，試験は，核融合科学研究所・低温実験棟に設置され ているクライオスタットを用いて行った。試験では，ガス ヘリウムを外部から供給し，これをクライオスタットの底 に溜めた液体へリウムで泠却し，さらに電気ヒータによっ

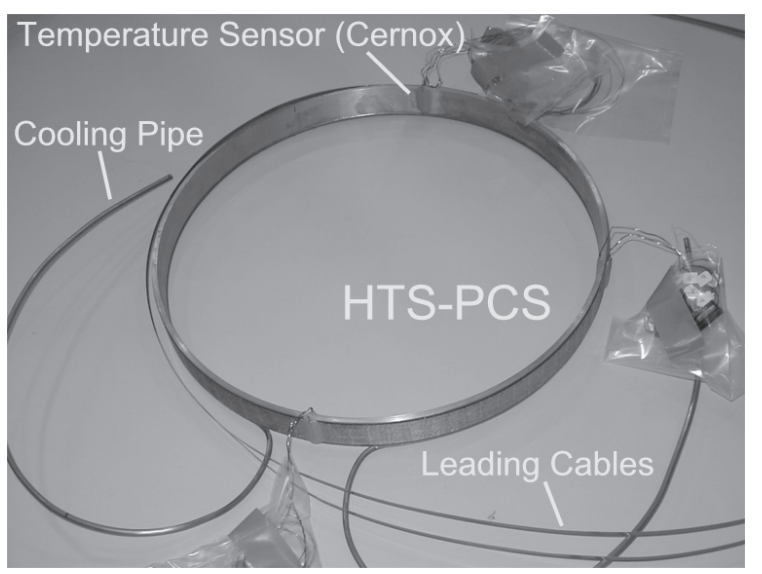

Fig. 5 Photograph of the prototype HTS-PCS developed for the Mini-RT project.

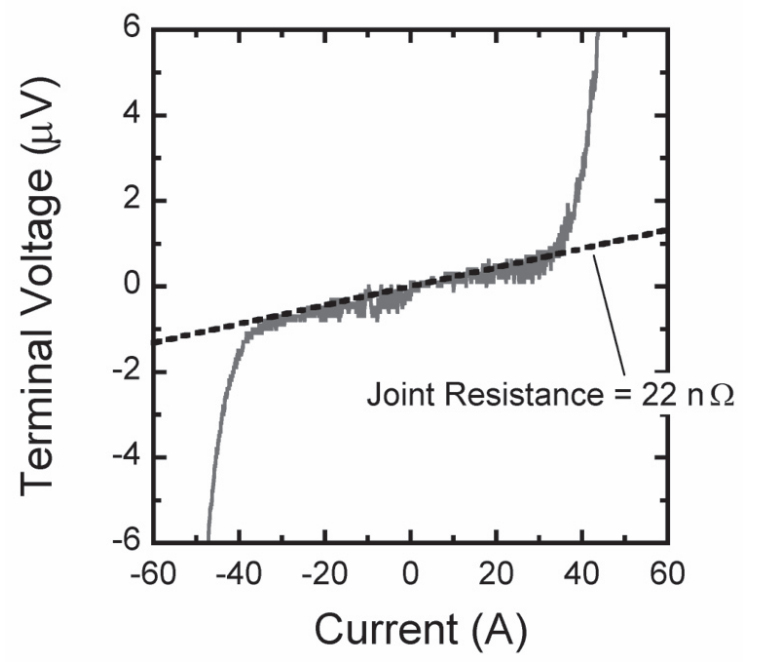

Fig. 6 Terminal voltage of the proto-type HTS-PCS as a function of the transport current applied in two directions, measured at $77 \mathrm{~K}$ with zero external magnetic field.
て温度制御して HTS-PCS に供給した。

試験では, まず $100 \mathrm{~mA}$ ほどの小電流を流した状態でマン ガニンヒータに通電して, HTS-PCS の温度が臨界温度 (約

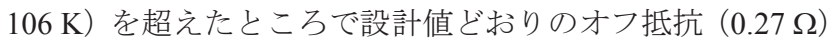
が得られることを確認した。. 次に, 実際の使用条件に近い 電流を流す試験を行ったが，その際に，巻線の両端電圧と 通電電流の関係について温度を $20 \mathrm{~K}$ から $77 \mathrm{~K}$ の範囲で变化

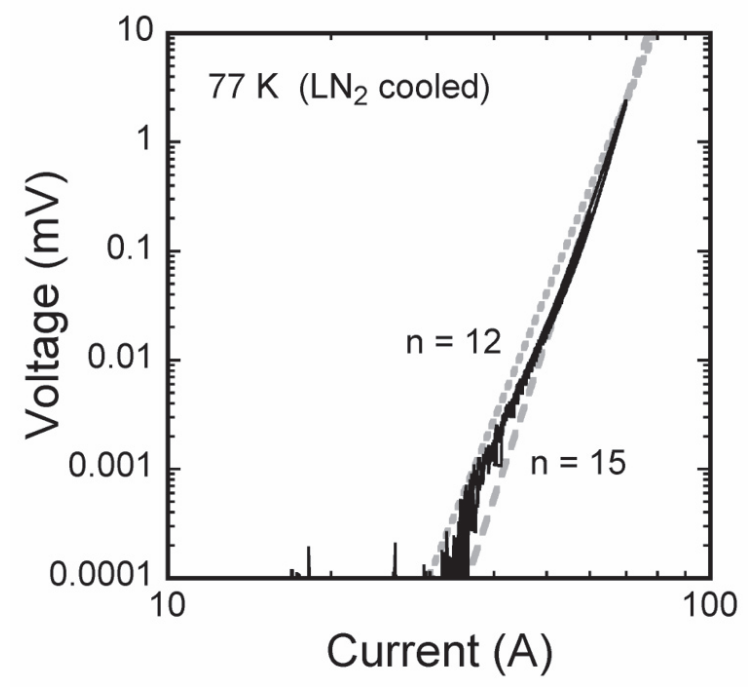

Fig. 7 Voltage versus current curve measured for the HTS-PCS cooled by liquid nitrogen. Two curves determined by the n-values of 12 and 15 are indicated by the dashed lines.

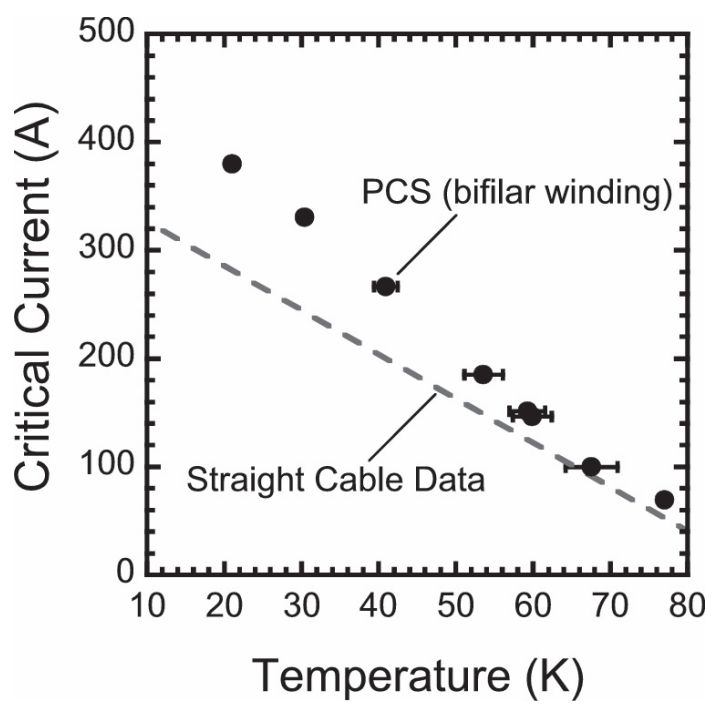

Fig. 8 Dependence of the measured critical current on the PCS temperature. Critical current for a straight sample is deduced for the present cable based on the empirical scaling given in Ref. 7). 
させて測定を行った，測定された電圧-電流曲線のうち，温 度 $77 \mathrm{~K}$ の場合（ただし，この場合は液体窒素による冷却） の結果を Fig. 6 に示寸. このグラフでは, 低電流領域につい て，測定された電圧を拡大してプロットしているが，これ によって接続抵抗を評価することが可能であり， $22 \mathrm{n} \Omega$ ほど であると求められる。また, 同じ測定結果について, この 接続抵抗分による電圧を差し引いたものを両対数グラフで プロットすると Fig. 7 が得られる。これより, 線材の $\mathrm{n}$ 值と しては 12 以上あることが実測できた。一方，Fig. 8 には, 発生電圧 $1 \mu \mathrm{V} / \mathrm{cm}$ の条件にて求めた臨界電流值の温度依存 性を示す，図中，横軸の温度に対して誤差があるのは, PCS の熱絶縁が十分でなかったために, 数個取り付けた温度計 の出力に差が出たためである. 得られた臨界電流は, 線材 単線に対して予測される値 $)^{2}$ 上りも高くなっているが, これ は, PCS の巻線方式がバイファイラとなっているために, 線材の作る自己磁場が単線の場合よりも低くなっているこ とが原因であると考えられる.

\section{Mini-RT 実機コイルの単体性能試験}

Mini-RT 装置実機の磁気浮上超伝導コイルの定格運転条 件では, $50 \mathrm{kA}$ のコイル電流が必要とされる。超伝導線材 には低銀比 1.57 の Bi-2223 線材が採用され，臨界電流は温 度 $77 \mathrm{~K}$ において $108 \mathrm{~A}$ である(自己磁場, $1 \mu \mathrm{V} / \mathrm{cm}$ の条件)。 テープ線材の絶縁としては， $50 \mu \mathrm{m}$ のカプトンテープが線

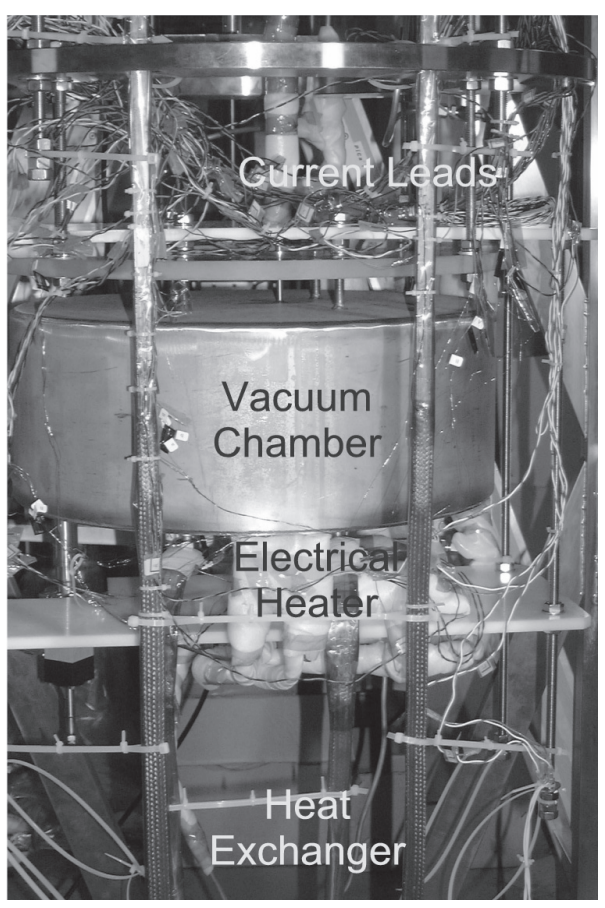

Fig. 9 Photograph of the experimental set-up of the HTS floating coil inside the cryostat for the second excitation test at NIFS. A tentative vacuum chamber was prepared for thermal insulation between the main coil and HTS-PCS.
材の両面に貼り付けられている. 浮上コイルはソレノイド 状に巻線され, 全長約 $420 \mathrm{~m}$ の線材を用いて 428 ターンで 構成された 5). 定格運転条件では, 線材 1 本あたりの電流 值は $116.8 \mathrm{~A}$ となる. コイルの定格運転時には, テープ面 に垂直方向に最大 $0.51 \mathrm{~T}$ の磁場が印加される. また, 平行 方向には，0.76 T である.

コイルの巻線作業が完了した後, 実際に Mini-RT 装置に 設置して磁気浮上実験を行う前に, コイルの単独試験を行 い, その特性を確認することが決定された。 そこで, 先に 行ったプロトタイプ HTS-PCS の単体試験と同様に, クライ オスタットを用いて性能試験を行うこととなった。この試 験でも, HTS-PCS の試験と同様に，外部から供給したガス ヘリウムを液体へリウムと熱交換することによって冷却 し, さらに電気ヒータを用いて温度制御し, これをコイル と PCSに供給した。ただし, コイルと PCS の冷却配管には バルブを設け, PCS をオフ状態とする際には, PCS 側の流 量制限ができるようにした，浮上コイルは，PCS がオン状 態のときには短絡コイルとなるため, 外部回路を用いてコ イル電流を測定することができない，そこでコイル中心に ホール素子を設置し，これを用いてコイル電流を測定する 方式を採用した.

クライオスタットを用いて行った最初の冷却・励磁試験 では，メインコイルと HTS-PCS のセットを簡易的にウレタ ンフォームの断熱材で覆うことによって試験の遂行を試み た.しかしながら，これではコイルと PCS の間に存在する ガスヘリウムによる熱伝導のために両者の間で十分な熱絶 縁が確保できず, PCS の温度を上昇させるとこれに合わせ

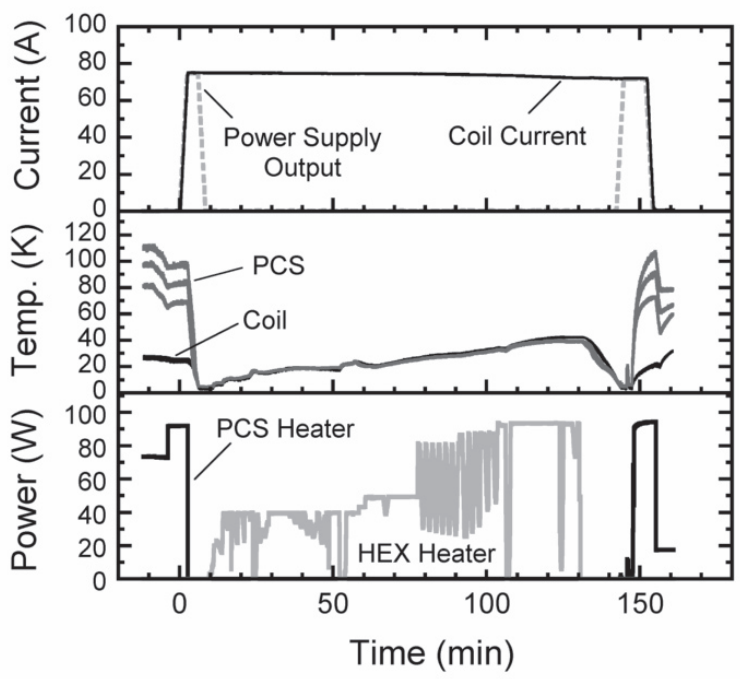

Fig. 10 Waveforms of the output current of the power supply, the coil current (evaluated by measuring the generated magnetic field with Hall probes), the temperatures of the coil and PCS, and the heater powers of the PCS and heat exchanger (HEX) during the second excitation test at NIFS. 


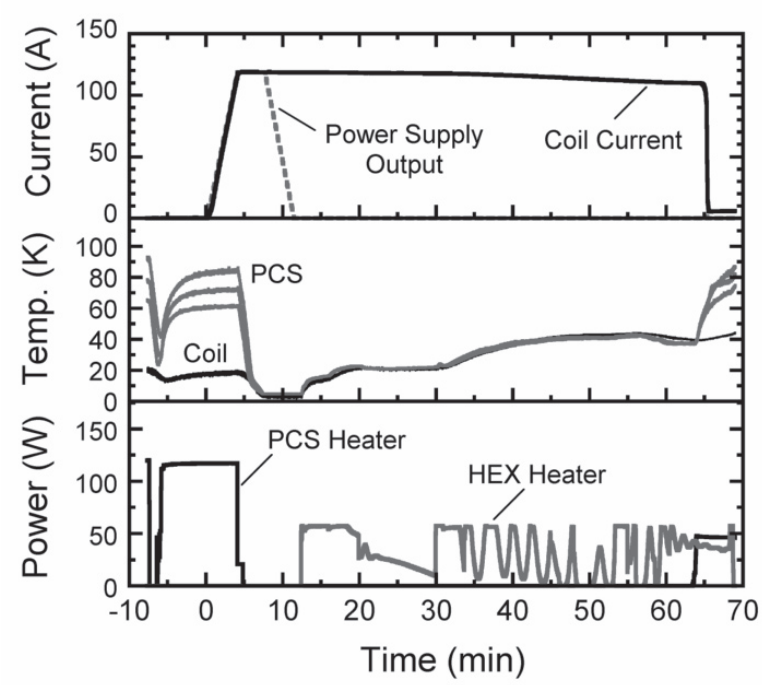

Fig. 11 Waveforms of the output current of the power supply, the coil current (evaluated by measuring the generated magnetic field with Hall probes), the temperatures of the coil and PCS, and the heater powers of the PCS and heat exchanger (HEX) when the nominal operation condition was achieved.

てメインコイルの温度も上昇してしまうという結果となっ た. 実際，メインコイルと PCS との間の温度差は最大で 30 K ほどに留まった。しかしながら，この温度差に応じてメ インコイルと PCS の両者で発生する磁束フロー抵抗の差を 利用して励磁を試みたところ，定格運転条件の約半分であ る線材電流 $64 \mathrm{~A}$ までの励磁を達成することができた．

次に, 2 回目の励磁試験では，メインコイルと PCS を仮 の真空容器に納めることによって両者の間の熱絶縁を確保 した. Fig. 9 に試験装置の写真を示寸. 仮の真空容器には, 電流導入用および計測用のフィードスルーを設けるととも に，冷却配管を貫通させた。この場合，Fig. 10 に示す通電 波形のように，メインコイルと PCS の間で十分な温度差が 確保でき，スムーズに励磁試験を行うことが可能となった.

励磁試験では，まずマンガニンヒータに通電することに よって PCS の温度を上げ，これをオフ状態としている. PCS の温度は 3 力所で測定されているが，各測定值にはかなり の差が認められる.これは, この試験のセットアップでは, コイルリード部を冷却する配管を PCS と同じ冷却配管とし てしまったために，PCS をオフにする際にもこれにある程 度の流量を流さなくてはならなかったことが原因であると 考えている.また，このことのために，PCS をオフにするた めには, 設計值の数倍の熱エネルギーを投入する必要もあ った.PCS がオフとなった後に，コイルの線材電流として 75 A までを励磁している。 このフェーズでは，ホール素子 を用いて評価したコイル電流と外部回路に設けたシャント を用いて測定した電源電流が良く一致している。この後,
マンガニンヒータを切ることによって PCS をオン状態とし て電源電流を下げたところ，コイル電流がそれまでの值を 保持し，永久電流モードに移行したことが確認できた。こ の例では, その後供給ガスヘリウムの温度を上昇させてい るために，永久電流は顕著に減少している. 次に， 2 時間 ほど永久電流を保持した後, 減磁動作を試みた。すなわち, まずホール素子で測定したコイル電流をもとに電源電流を それに一致するところまで上昇させ，その後 HTS-PCS をオ フ状態として電源電流を下降させたところ, これに合わせ てコイル電流も減少させることができた。これにより, 減 磁動作についても, 通常の永久電流スイッチと同様に機能 することが実証できた。

以降の励磁試験においては，Fig. 11 に示すように，線材 の電流值として定格（116.8 A）以上の $118 \mathrm{~A}$ まで到達する ことに成功した。ただ，この例では，最後にコイル温度 を上昇させることによって減磁を行っている。 また，この 実験では，永久電流の保持中に温度を約 $20 \mathrm{~K}$ ，および，約 $40 \mathrm{~K}$ に固定して永久電流の減衰測定を試みたが，保持時間 が各 10 分程度と短かったために, 減衰時定数を正確に評価 するには至らなかった。（永久電流の減衰時定数の正確な 測定については，実機 Mini-RT において行った励磁試験で 行った結果を文献 10）に記載.）

以上の試験により, Mini-RT の HTS 磁気浮上コイルが, コイル単体として問題なく機能することが実証できた。こ の後, 超伝導コイルは実機の真空容器に納められ, 実際の システムを用いて以降の励磁試験を行うこととなった ${ }^{10)}$.

\section{5. まとめ}

内部導体磁気浮上装置 Mini-RT の開発を行うために, HTS 磁気浮上コイルシステムの研究開発を行った. 銀シース Bi-2223 テープ線材を用いてミニチュアの HTS コイルを製 作し，大気中において磁気浮上デモンストレーションを行 うことに成功した。次に, 永久電流スイッチ(HTS-PCS)の プロトタイプについて, 液体へリウムを有したクライオス タットで単独試験を実施し, 問題なく開発できたことを確 かめた. Mini-RT 実機用浮上超伝導コイルの完成後には, ク ライオスタットで特性試験を遂行し, HTS-PCS を用いて永 久電流モードの励磁が行えること, および, 定格運転条件 までの励磁が行えることを確かめた.

本研究論文をまとめるにあたり, HTS 磁気浮上コイルの 設計・製作を担当された（株）日本 $\mathrm{AE}$ パワーシステムズの 伊藤郁夫氏，富士電機アドバンストテクノロジーの（株） 能瀬眞一氏に感謝申しあげます。本研究の一部は, 核融合 科学研究所の LHD 計画共同研究, および, 科学研究費 (課 題番号 14580532）によって助成されました. 


\section{参 考 文 献}

1) S.M. Mahajan and Z. Yoshida: "Double curl Beltrami flow: diamagnetic structures," Phys. Rev. Lett., 81 (1998) 4863-4866

2) Y. Ogawa, et al.: "Design of a toroidal plasma confinement device with a levitated superconducting internal coil," AIP Conf. Proc. (1999) 417-422

3) Y. Ogawa, et al.: "System design of a magnetically levitated internal coil device Mini-RT,” J. Cryo. Soc. Jpn. 39 (2004) 175-181 (in Japanese)

小川雄一ら:「磁気浮上内部導体装置 Mini-RT の全体設計」, 低 温工学 39 175-181 (2004)

4) J. H. Schultz, et al.: “The Levitated Dipole Experiment (LDX) magnet system,” IEEE Trans. Appl. Supercond., 9 (1999) 378-381

5) T. Mito, et al.: "Design and construction of the Mini-RT device," J. Cryo. Soc. Jpn. 39 (2004) 182-192 (in Japanese) 三戸利行ら：「Mini-RT 装置の設計・製作」，低温工学 39 182-192 (2004)

6) L. Masur, et al.: "Long length manufacturing of high performance BSCCO-2223 tape for the Detroit Edison power cable project," IEEE Trans. Appl. Supercond. 11 (2001) 3256-3259

7) T. Kaneko, et al.: "Status of Bi-2223 tapes performance and development," IEEE Trans. Appl. Supercond., 9 (1999) 2465-2468

8) K. Tasaki, et al.: "Cryocooler-cooled Bi-2223 superconducting magnet carrying persistent current," Proc. MT-15, Science Press, Beijing, China (1998) 812-815

9) J. Morikawa, et al.: "Levitation experiment using a high-temperature superconductor coil for a plasma confinement device,” Jpn. J. Appl. Phys. 40 (2001) 1029-1031

10) N. Yanagi, et al.: "Cool-down and Excitation Tests of the HTS Floating Coil in the Mini-RT Project,” J. Cryo. Soc. Jpn. 39 (2004) 201-208 (in Japanese)

柳 長門ら：「Mini-RT 装置用高温超伝導磁気浮上コイルの冷 却・励磁試験」, 低温工学 39 (2004) 201-208

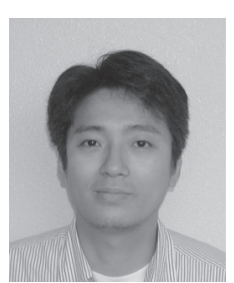

昭和 45 年 10 月 12 日生. 平成 5 年東京工業 大学理学部応用物理学科卒業. 平成 10 年同大 学大学院総合理工学研究科創造エネルギー専 攻博士課程修了. 同年 7 月より核融合科学研 究所勤務. 主として超流動ヘリウムの熱輸送 に関する研究に従事. 低温工学協会, プラズ マ・核融合学会会員. 博士(工学).

菱 沼 良 光

昭和 46 年 8 月 16 日生. 平成 8 年 3 月東海大 学大学院工学研究科博士前期課程修了. 平成 11

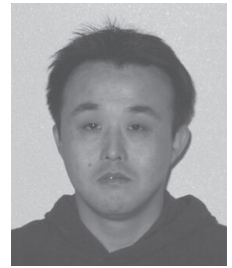
年 3 月筑波大学工学研究科博士課程修了. 同年 4 月明星大学先端材料研究開発センタ一勤務, 酸化物超伝導材料開発に従事. 平成 13 年 7 月 文部科学省 核融合科学研究所 大型ヘリカル 研究部 装置技術研究系 助手. 平成 15 年 4 月 炉工学研究センタ一助手に配置換 (平成 16 年 4 月, 大学共同利用機関法人 自然科学研究機構 核融合科学研究所 炉工学研究センターに改称). 主に低放射化超 伝導導体開発に従事. 低温工学協会, 日本応用物理学会, 日本金 属学会会員. 博士 (工学).
三 戸 利 行 （本特集の三戸論文参照）
森 川 惇 二（本特集の森川論文参照）
小 川 雄 - （本特集の小川論文参照）
大 國 浩太郎 （本特集の小川論文参照）
堀暖 （本特集の小川論文参照）
岩 熊 成 卓 (本特集の小川論文参照)
上 出 俊 夫 (本特集の小川論文参照)

柳長 門 1962 年 12 月 24 日生. 1989 年 12 月京都大学

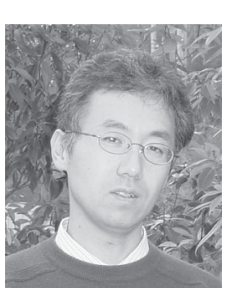
大学院工学研究科博士後期課程中退. 同 12 月, 文部省 核融合科学研究所 大型ヘリカル研究 部 装置技術研究系 助手. 2000 年より同助教授 (2004 年 4 月より, 大学共同利用機関法人 自 然科学研究機構 核融合科学研究所大型ヘリ カル研究部 炉システム・応用技術研究系に改 称). 主に, 大型ヘリカル装置 (LHD) のヘリ カルコイルとその超伝導導体に関する電磁現 象を中心とした特性研究に従事. 低温工学協会, 日本物理学会, プラズマ・核融合学会会員. 博士 (工学) 